\title{
THE PUBLIC ADMINISTRATION IN FRONT OF CURRENT CHALLENGES IN GREECE AND EUROPE
}

\author{
Author(s) / Auteur(s) : \\ Georgia CHRONOPOULOU \\ PhD Candidate at Panteion Uni of Athens, \\ Political and Social Dept \\ gchr123@gmail.com
}

\begin{abstract}
Résumé :
Reforms in EU member states as well in Greek public sector are based upon the Refit system. Main purpose is the "catharsis" of Greek public sector in order to reduce the deficiency of General Government according to the MO's programs. That caused redundancy, mobility, availability of the public servants. The main purpose is to regulate the state upon principles appropriate to the agreed objectives of Lisbon treaty that must be flexible. This kind of flexicurity is based on a highly competitive social market economy via the precarity system in order to diminish the economic crisis.
\end{abstract}

Keywords / Mots-clés :

public sector, civil servants, employment, precarity job system

\section{INTRODUCTION}

The topic into question is to analyze the reforms taken by the assessment of political decisions concerning the Greek economic crisis. The results of the reforms caused changes in the public sector for the period of years 2008-2018 aimed at the modernization of the Greek public administration. The state's reduction took place in the years 2009-2015 realizing the MO's programs. These institutional programs imposed apart of monetary sanctions the redundancy, the reserve, the availability and the mobility of civil servants to follow a new "Cartesian model" to the resolution. The last three years the roll-out of the state had led to the publication of a series of institutional notices in order to fill vacant posts. The vacancies aim to function properly the public administration of the State. It is obvious that the description of the work object according to a series of fixed-term contracts to an indefinite period to end up into prosperity. The same opinion is expressed to the barometric statistics of EU (2013) that "a slight improvement, a very large majority of Europeans remain negative about the employment situation in their country. The difficult situation of high level of unemployment is increasing in EU. The economic crisis plus the increasing of immigration flow started in autumn 2013-15: the 74\% of European citizens think that the situation is "bad". The agenda of EU is to regulate economic and social policies according the European and national level that are complementary and reinforcing mutually. Till today (2019) although the inflation is appeared to be reduced, the economic situation of EU' state members is considered to remain without resolution. The case of Greece, state member of the EU.

\section{HISTORICAL POINTS}

Historically the public administration of Greece relies on the Athenian rule concerning the state function "ergon" that means "the "work" in the public domain or the "res publica" in the roman's period. The modern public service is changed. It is necessary to assimilate to the contemporary demands, new forms of recruitment especially the "precarity employment" according to the article of Maastricht and Lisbon Treaty. This employment model is a mean to tackle the economic crisis as a kind of labor reinforcement into "precariousness". It is an employment system well known since the Marx's era, that is became the antidote to a rising unemployment system that income inequalities, 
vulnerability, sustainability and resilience capacity were able to "confront" any kind of crises. The incorporation of political acts into administrative law requires institutional consensus seeking to reduce bureaucratic costs in a democratic context (REFIT) COMMISSION DECISION of 19.5.2015 establishing the REFIT Platform Strasbourg, 19.5.2015 C (2015) 3261 final, in order to Communication Better Regulation for Better Results - An EU Agenda.

\section{THE MODERNIZATION OF PUBLIC ADMINISTRATION: THE REFIT SYSTEM}

The implementation of political decisions influences the economic situation state and its welfare system. To tackle and manage challenges are aiming to reduce crises problems by using private initiatives into public administration. Public culture evaluates initiatives with or without the general and comparative interest. The modernization and strengthening of administrative acts is that the public administration manages many risks to the future of society. This possibility provided by reforming administration as well to meet the challenges of the economic crisis. The globalization and the international situation are aiming at the implementation of European directives through the Parliament's Institutional Harmonization Office to evaluate, distribute the results of the European (Decisions-Guidelines-Regulations). The question is "if the action of evaluation is implied in the political action and the degree of the European effect".

\section{THE "ELITE" CONTRIBUTION: THE PUBLIC SERVANTS- THE EVALUATION SYSTEM}

The famous "pacta sunt servanta" is subjected to crisis reduction (socio-economic) by modernizing the public administration as well the system of refolding the state. The constitutional safeguarding of these decisions is in line with the provisions of paragraph 3 of Article 28 of the Greek Constitution. According to Jacques Chevalier the public administration defines the political act in the context of "normative common sense deriving from the administrative framework" (1993: 15). The Greek public administration moves in a democratic context, respecting the human rights, the citizen and the society as well. Its immediate transformation into a policy instrument or decisions are taken into consideration the common policy of EU that concerns the third stage for the future of Europe (i.e. solidarity, subsidiarity, social and territorial cohesion art.3), which will be discussed as it is described below. The ambitious goal of EU is to "sustain development based on competitive social market economy". For over a decade this mechanism has not been implemented efficiently because of the lack of strategy on behalf of EU.

The evaluation of the public sector via civil servants of Greece (1. 4440/2016) seeks a threefold approach to confront vulnerability. The result is not well expected due to the fact that plasmatic opinion by the rated highly recommended is not identified with the inputs and outputs of work progress in the public sector. Any kind of crises are resolved with crises not only social but by all means of the side of the state. It is the way to tackle with «the social values or the willingness to transform the Public Administration into better situation" (XIXs). It is too far to modernize or to spoil the Greek administrative system under the merit mechanism according to the sayings of the American President Wilson (1887). "The relation between the Public Administration and public servants is expressed by the philosopher Jeremy Bentham's definition concerning the public servant's corpus that expresses the qualities of a civil servants which are far from" an individual person. The "official institution" does not function and comprehend the conception of why Bentham calls that the public official must be distinguished. He attributes to that three characteristics of the "elite body": "morality, ability that consistent with the spiritual ability and effectiveness". There is lack of the average level of the last three points concerning the body of civil servants' where the customer-centricity spoils the meritocracy system. 


\section{CONCLUSION}

As far as it concerns the recruitment of the Greek public administration, permanent or seasonal, the functioning of the public administration is made up of employees who are distinguished by the zeal of "industrialism" according to the utilitarian principle. This relationship determines citizen-state relationships as J. Bentham's beliefs that civil servant is the body of the administration, able to proceed "en aval ou en amont du recrutement des fonctionnaires". In the recruitment process, J. Bentham goes further on the selection process, information provision, transparency and ethics for which a prospective civil servant must be distinguished. It is a qualification ability to restrain and to prevent candidate without the necessary qualities for the body of civil servants. «Inadequate» person, upon the philosopher's opinion, is based on the corruption of bureaucratic system which must be dispatched far from a competent civil servant with distinguished ability, to manage the work with according to the principle of maximin control capacity. By this way the map of government is going to fulfill the Refit's regulation that is to harmonize the administration system of members state of EU.

\section{BIBLIOGRAPHY}

Céline Belot, Paul Magnette, Sabine Saurugger (2008) Edition ECONOMICA Collection d Etudes Politiques, Science politique de l'Union européenne

Chevalier, J., « La politique française de modernisation administrative », L'Etat de droit, Mélange (...) Chevalier, Jacques, (1993) «Les fonctionnaires et la modernisation administrative », Revue

Françoise Dreyfus Jean -Michel Eymeri (2006) Edition ECONOMICA Collection d Etudes Politiques 2006, Science politique de l'administration (une approche comparative)

Herrman Peter, Kalaciogly Sibel (2011), Ed. Vol. XVI "Precarity - More Than a Challenge of Social Security: Or: Cynicism of EU's".

P. BEZÈS, (1962-2008) Ré-inventer l'Etat. Les réformes de l'administration française, Paris, PUF,

ROUBAN, L. (2000) "Les cadres supérieurs de la fonction publicque et la politique de modernisation administrative"

Spanou Kalliopi (2000), «Administration, Citizen and Democracy », Athènes

Strasbourg, 19.5.2015 C (2015) 3261 final COMMISSION DECISION, establishing the REFIT Platform

The Treaty of Lisbon (2007) 
